DOI https://doi.org/10.51647/kelm.2020.4.1.39

\title{
CONCEPTUAL APPROACHES IN LAW TO THE CONCEPT OF THE AGRARIAN MARKET DEFINITION
}

\author{
Yuliia Pavluchenko \\ Ph. D. in Law, Associate Professor, \\ Associate Professor at the Department of Commercial Law \\ Vasyl' Stus Donetsk National University (Vinnytsya, Ukraine) \\ ORCID ID: 0000-0003-1504-8384
}

\begin{abstract}
The agrarian market is the subject of legal regulation, so there is a necessety to its clear legal definition. The research is based on the approach that the concept of the agrarian market is the developing one and it was derived from the concept of the market. During the research, using the system method, the method of analysis and synthesis and the formal-legal method, the determination of the definition of the concept of the market and the agrarian market from the variety of the scientific sources, the legislation of Ukraine and some other countries, was carried out. Among the available scientific approaches to the definition of the market, it was found that in the legal science, the agrarian market is mostly understood as a sphere of trade, a system (set) of social relations or a mechanism of regulation. It was proved that for the general legislative definition of the agrarian market it is possible to consider the understanding of this concept as a system of social relations regulated by the rules of law that arise in relation to the sale of agricultural products as a principle. At the same time, in the context of improving the legal regulation of the agrarian market, it is also necessary to take into account the defining approaches to the agrarian market as a sector of commodity circulation and a mechanism for regulating the interaction between the potential sellers and buyers.

Key words: market, agrarian market, sector of commodity circulation, system of legal relations, mechanism, agricultural products.
\end{abstract}

\section{КОНЦЕПТУАЛЬНІ ПІДХОДИ У ПРАВІ ДО ВИЗНАЧЕННЯ ПОНЯТТЯ АГРАРНОГО РИНКУ}

\author{
Юлія Павлюченко \\ кандидат юридичних наук, дочент, \\ дочент кафедри господарського права \\ Донецького наиіонального університету імені Василя Стуса (Вінниия, Україна) \\ ORCID ID: 0000-0003-1504-8384
}

\begin{abstract}
Анотація. Аграрний ринок є предметом правового регулювання, тому потребує однозначного правового визначення. В основу дослідження покладено підхід, що поняття аграрного ринку розвивається і $є$ похідним від поняття ринку. У ході дослідження з використанням системного методу, методу аналізу й синтезу та формально-юридичного методу проведено аналіз різних наукових джерел, законодавства України й деяких інших країн щодо визначення поняття ринку та аграрного ринку. Серед наявних наукових підходів до визначення ринку з'ясовано, що у правовій науці аграрний ринок здебільшого розуміють як сферу товарообігу, систему (сукупність) суспільних відносин або механізм регулювання. Доводиться, що для загального законодавчого визначення аграрного ринку за основу можна брати розуміння цього поняття як системи суспільних відносин, урегульованих нормами права, які виникають щодо реалізації сільськогосподарської продукції. При цьому в контексті вдосконалення правового регулювання функціонування аграрного ринку також потрібно враховувати підходи до визначення аграрного ринку як сфери товарообігу сільськогосподарської продукції та механізму регулювання взаємодії між потенційними продавцями й покупцями.
\end{abstract}

Ключові слова: ринок, аграрний ринок, сфера товарного обігу, система правовідносин, механізм, сільськогосподарська продукція.

\section{PODEJŚCIA KONCEPCYJNE W PRAWIE DO DEFINIOWANIA POJĘCIA RYNKU ROLNEGO}

\author{
Yuliia Pavliuchenko \\ kandydat nauk prawnych, docent, \\ docent Katedry Prawa Gospodarczego \\ Donieckiego Uniwersytetu Narodowego im. Wasyla Stusa (Winnica, Ukraina) \\ ORCID ID: 0000-0003-1504-8384
}

Adnotacja. Rynek rolny jest przedmiotem regulacji prawnych, dlatego wymaga jednoznacznej definicji prawnej. Podstawą badania jest podejście, że pojęcie rynku rolnego rozwija się i wywodzi się z pojęcia rynku. W trakcie badania $\mathrm{z}$ wykorzystaniem metody systemowej, metody analizy i syntezy oraz metody formalno-prawnej przeprowadzono analizę 
różnych źródeł naukowych, prawa Ukrainy i niektórych innych krajów w zakresie definicji pojęcia rynku i rynku rolnego. Wśród dostępnych naukowych podejść do definiowania rynku okazuje się, że w naukach prawnych rynek rolny jest rozumiany głównie jako sfera obrotu towarowego, system (całość) stosunków społecznych lub mechanizm regulacyjny. Uzasadniono, że do ogólnej definicji legislacyjnej rynku rolnego podstawą może być zrozumienie tego pojęcia jako systemu stosunków społecznych uregulowanych normami prawa, które powstają przy sprzedaży produktów rolnych. Jednocześnie w kontekście poprawy regulacji prawnych funkcjonowania rynku rolnego należy również wziąć pod uwagę podejścia do definiowania rynku rolnego jako sfery obrotu produktami rolnymi i mechanizmu regulacji interakcji między potencjalnymi sprzedawcami i nabywcami.

Słowa kluczowe: rynek, rynek rolny, zakres obrotu towarowego, system stosunków prawnych, mechanizm, produkty rolne.

Introduction. The term "market" has become widely used. In practice, the relationships of the paid exchange of tangible and intangible objects are called the market, and at the same time there is a large number of markets depending on the object of exchange. The agrarian market is the one type of the market, which plays an important role in the agricultural sector of the economy. Stability and resistant positive indicators of the agricultural activity depend on the stable functioning of the agrarian market with the well-established infrastructure and transparent connections between its participants.

Naturally, the market has been the subject of scientific research. Such studies are devoted to the various market aspects including the concept of the market (Baker, 2007; Kaplow, 2013). At the same time, there is the opportunity to come across the studies based on the generalization and evaluation of the well-known theories about the concept of the market in the Ukrainian scientific environment (Bachurina, 2009; Hrigoryev, Kvasha, 2016 and others). Among the studies are those that are focused on the market analysis in the context of monopolistic and competitive relations (Carlton, 2007; Crane, 2014).

In general, it is possible to state the existence of the established conceptual views on the concept and the essence of the market in economics, on which the Ukrainian researchers also rely. At the same time, the traditional definition of the market has come under criticism (Crane, 2014: 32). There is no unity of views on the concept of the market in law. At the same time, the concept of the market is important both as an object of scientific research and as a legal definition for countries in a state of active development of market relations. The more profound and deeper understanding of the market essence allows us to identify those aspects and elements of the market, as well as the processes that require the attention of the state and legislation.

The aim of this research is summarizing of the existing conceptual approaches to the definition of the concept of the market and agrarian market and their evaluation in the context of improving the legal regulation of the agrarian market.

To achieve the defined aim, it is necessary to analyze scientific and other sources, to clarify and summarize views on the concept of the agrarian market. The variety of scientific sources, which were developed using the system method, the method of analysis and synthesis, were considered as the research materials along with the legislation, which contains the definitions of the concept of the market and the agrarian market, and for the analysis of which the formal-legal method was used.

At the present stage of the development of a society and science, it is possible to state the existence of such concepts that belong to the intersectoral categories. Due to the complexity and diversity of the phenomena they denote, these concepts can not be unambiguously defined, even within one branch of science. Such intersectoral categories should contain the concept of the market and its derivatives, including the concept of the agrarian market.

It is believed that the market emerged as a result of the all-round division and specialization of labor, which led to the acquisition of the produced products the features of the goods. The agricultural production was one of the first goods, so the agrarian market has a long history of the development and to some extent an established system of scientific views on it. Such scientific concepts can be used to form a common understanding of the agrarian market at the state level, which will increase the effectiveness of the state regulation of the agrarian market.

Today we can talk about the concepts of the market and the agrarian market, in particular, in science, in legislation and at various levels of practice. It is necessary to dwell on their analysis in future.

The term "market" is defined in several senses in dictionaries. The market may indicate the place of retail sale of food and other goods; a place where something is sold; the sector of commodity exchange; the supply and effective demand for goods on the scale of the world economy, the country or its certain districts (Slovnyk ukrainskoi movy, 1977: 536).

Thus, the market has many definitions and interpretations, which only emphasize the intrinsic complexity of this concept and the possibility of filling it with the content depending on the subject of its interpretation, the field of social science, the purpose and scope of its interpretation. However, there are opinions that it is impossible to define the market (Kaplow, 2013: 361).

First of all, the market is an economic category. In this aspect, the market is an integral attribute of a market economy, a form of commodity-money circulation (exchange), which is interrelated with the sphere of production.

In general, there are several well-established approaches to understanding the market. In particular, the market can be defined: 1) as a spector of commodity circulation; 2) as a socio-economic system of relations between the sellers and buyers; or as a system of monetary relations; as a system of economic relations between the market participants; 3) as a system of institutions, methods, resources that bring together the sellers and buyers of a particular product and to coordinate and manage agro-industrial production; 4) as a set of legal relations and 5) as a certain place of trade, where agreements are concluded between the sellers and buyers (Hrigoryev, Kvasha, 2016: 58; Pavlenchyk, 2014: 86-87). It is believed that the last of these approaches to understanding the market was one of the first and today reflects mainly the everyday view of such a phenomenon as the market. 
The view of the market as a sphere of trade (exchange) can be considered purely that emphasizes the purpose, the main purpose of the market and the processes that take place in it. The definition of the market as a sector of commodity circulation can be found in the encyclopedic sources, in the scientific papers and educational literature (). Sometimes this definition is concretized, indicating that the market is a sphere of real turnover and it must be distinguished from trade, because the market is a special economic category, and trade is a branch of the economy (Kalaman, 2015: 53).

At various stages of the functioning of the market and the research of its essence, the understanding of the market as a certain system (set) of connections or relations has become quite common. Today, for example, the market is proposed to be defined as a set of economic relations between the individuals or legal entities, the government and the supranational bodies for the organization and purchase and sale of various goods and services in accordance with the laws of commodity production (Ekonomichna entsyklopediia, 2002: 235).

At the same time, the understanding of the market as a sphere of trade and a set of specific economic relations indicates the focus of attention in this concept on various aspects. Thus, if the object of the market relations is important for the sector of commodity exchange, e.g. goods (products, services), then for the market as a set of (economic) relations the relations between specific individuals (market participants) about the object of exchange are at the first place.

The ongoing research for the most optimal interpretation of the market have been resulted in the market being considered as a certain type of economic relations and, accordingly, the concept of a market mechanism came into circulation.

Characteristics of the phenomenon as a mechanism (or process) suggest that such phenomenon is a complex in structure, framework; its elements are consistent with each other and represent the system; such a phenomenon is capable of dynamic purposeful activity and tends to the self-management and to/or the external management (Prylutskiy, 2013: 34).

Thus, the conceptual definition of the market was formulated by R. McConnell and S. Brew, who proposed to consider the market as an institution and mechanism that brings together the buyers (representatives of demand) and sellers (suppliers) of the certain goods and services. According to another definition, the market is a special mechanism of interaction between the seller and buyer to determine the price and quantity of goods (Smahin, 2008: 10).

Based on the above mentioned views, the opinion is formed today that the market is a complex mechanism for identifying and reconciling of economic interests, a certain way of organizing economic life, which is characterized by the independence of its participants, by the commercial nature of their interaction, by the competition, by the pricing based on supply and demand (Nikolenko, 2007: 119).

The understanding of the market as a mechanism is fully described in the pricing of objects of circulation. The relations between the sellers and buyers in the market were so free for a long time that the prices for the same goods could be quickly and easily equalized (Hrigoryev, Kvasha, 2016: 56). However, at the present stage of the functioning of some types of market, including the agrarian, it is under the influence of a combination of market mechanism and state regulation of the economy and is revealed within the economic and legal mechanism of insurance the of the market functioning.

It can be argued that the concept of the agrarian market is considered under the influence of the above views on the general concept of the market in the Ukrainian science.

For example, the agrarian market is also defined as the sphere of interaction of the market participants, the sphere of circulation of agricultural and food products, the sphere of circulation of relevant goods (Kyrylyuk, 2011). Also, the agrarian market can be considered as a holistic institutional system or the economic area, social, economic, sectoral relations of all economic entities, whose task is the process of cooperation and management, which are carried out in the terms of production, exchange, storage, transportation, distribution and purchase of agricultural products (Mamchur, 2013). Along with the considerable quantity of supporters of the definition of the market as a system (set) of relations, at the same time consider that such relations between the sellers (manufacturers) and buyers provide a creation and the efficient functioning of the entire agro-industrial complex, not just agriculture, in the agricultural sector of the economy.

In Ukrainian jurisprudence, less conceptual views on the concept of the market and agrarian market, in particular, have been formed. Thus, in commercial law, the analysis of the concept of the market, for the most part, takes place within the study of markets of certain types, such as pharmaceutical (Voron, 2015: 4), stock (Polyukhovych, 2012) and others. In the most general sense, the market is considered as a regulated system of social relations that arise between businesses and other participants in legal relations regarding the paid alienation of the products or services.

The understanding of the market as a system (set) of relations governed by the rule of law, can be considered the most acceptable in law, because the public relations are the subject of legal regulation (including various branches of law). Applying the realization of legal relations, it is possible to characterize the market, to form an idea of it as a legal concept, to define it.

The market is also proposed to be interpreted as a complex mechanism for regulating economic and legal relations between existing and potential carriers of supply and demand for the most profitable exchange of products, services and other goods, in compliance with the payment rules, based on the commodity-money relations and economic freedom in society and are regulated by the state (Kutsenko, 2012: 12).

At the same time, the opinion is expressed that, for example, the stock market is a functional system of the participants, their actions and legal relations regulated by law (Polyukhovych, 2012: 4). A similar definition 
is proposed for the agrarian market, namely: as a system of institutions, relations and principles of operation that provide the exchange processes between the agricultural producers and their consumers, processing enterprises or end users (Bachurina, 2009: 111).

Regarding the agrarian market, it is considered doctrinal to define it as a sphere of commodity exchange that (within the legislation on agricultural markets) is carried out between the sellers and buyers (legal entities, individuals, local communities, the state) as a trade arising from the agricultural production in the established places, forms by making and executing contracts of sale, other civil transactions on a voluntary agreed terms and at appropriate prices and the will of sellers and buyers (Semchyk, 2012: 225).

It is logical to assume that the above mentioned scientific views on the concept of the market and the agrarian market, in particular, have left their mark on the definition of this concept in legislation. In these processes, the thesis is confirmed that the economic meaning of the phenomenon of public life is primary in the relation to its legal essence and legal certainty of this phenomenon. At the same time, at the present stage, the scientific views on the concept of the market are also formed taking into account the state of legislation.

The legislation of some post-Soviet countries, in particular, the Russian Federation, the Republic of Belarus, Kazakhstan, Ukraine and Moldova, has fixed the definition of the market. The relevant definitions are contained mainly in the tax legislation and/or legislation on protection of economic competition. From the analysis of laws it follows that the market is defined either as a sphere of circulation of goods, or as a system of certain relations.

Focusing in more details on the analysis of the Ukrainian legislation, it should be noted that the regulations contain thirteen definitions of the concept of the market. In these definitions, the market acts as: 1) an entity whose responsibilities include the creation of appropriate conditions for sellers and buyers to buy and sell goods at prices that depend on supply and demand; 2) a specially designated and equipped place for the provision of services for the sale of goods; 3 ) the sphere of trade and others (Terminolohiya zakonodavstva, 2020). Along with the definition of the concept of the market, the Ukrainian legislation also enshrines the definitions of derivative concepts, including the definition of the agrarian market as a set of legal relations related to the conclusion and implementation of civil contracts for agricultural products (Pro derzhavnu pidtrymku sil's'koho hospodarstva Ukrayiny, 2004).

In the scientific community, this definition is perceived ambiguously. Some researchers point out that the legal definition of the agrarian market gives grounds to consider it as a system of economic and legal relations and the provisions of which are the legal mechanism aimed at ensuring a continuous relationship between the producers and consumers of agricultural products (Pavlenchyk, 2014: 88). Instead, others actively criticize it (Kyrylyuk, 2011), in particular, the main argument is that in the agrarian market, objects can be not only the agricultural products, but also other goods.

For example, in the Russian Federation the definition of the market of agricultural products, raw materials and food is fixed as a sphere of circulation of agricultural products, raw materials and food (O razvitii sel'skogo khozyaystva, 2006) is fixed.

Summarizing the legal definitions of the market, the agrarian market and similar concepts, it should be noted that conceptual views on the market concepts and legal definitions intersect in terms of market definitions as a sector of circulation or as a system of relations. In this regard, it can be concluded that these definitions of the market reflect the essence of the market as a legal category better and are the most suitable for achieving the goals and objectives of legislative regulation in a particular area.

In addition to the question of what the agricultural market is: the sector of commodity circulation, the system of relations or the mechanism of interaction between the buyers and sellers, there is another question to consider. What is it the object of circulation in the agrarian market? The answers to this question are also ambiguous.

For example, from the definition of the agrarian market as a sphere of interaction of the market participants to ensure the production and free movement of the agricultural products, food products, technologies, the means of the production and services for the agro-industrial complex, agricultural scientific and technical products (Mamchur, 2013) follows a wide range of objects in this market.

A wide range of objects is also indicated by the provisions of the Agreement on the Common Agrarian Market of the Commonwealth of Independent States, which stipulates that the common agrarian market of the Commonwealth of Independent States provides free movement of the agricultural products, foodstuffs, scientific and technical products and technologies, the means of the production and services for the agro-industrial complex of national origin (Uhoda pro spil'nyy ahrarnyy rynok, 1998).

However, the researchers have the well-founded objections to such a wide object as the structure of the agrarian market, in particular, because of the means of the production, services, scientific and technical products, etc. are the objects of independent markets and it is doubtful to include them into agrarian market only because they are consumed by agricultural producers (Kyrylyuk, 2011). Some objections to the including of food products in the agrarian market can be added to this, as most of them are the result of the functioning of the food industry, and agricultural products are raw materials for the food production.

Also, such a wide range of goods that are considered to be the objects of the agrarian market, significantly expands the boundaries of this market, which may adversely affect both the specification of elements of such a market and the choice of state regulation, to reduce the effectiveness of state agricultural policy market.

The answer to the question of specifying the objects of the agrarian market can be found in the plane of a literal interpretation of the term "agrarian market", which indicates that it is an exchange of products obtained as a result of land use (Pavlenchyk, 2014: 88). Based on this, it is possible to offer the object of circulation in the agrarian market to consider the agricultural products. 
This conclusion is in line with the provisions of the Treaty on establishing the European Community as amended. In particular, in Article 32 of the mentioned Treaty it was stipulated that the common market covers agriculture and trade of agricultural products. At the same time, agricultural products are the products grown on land, livestock and fishery products, as well as primary processing products directly related to these products (Reaty on the Functioning of the European Union, 2005). A similar definition of agricultural products is also contained in the Ukrainian legislation (Pro derzhavnu pidtrymku sil's'koho hospodarstva Ukrayiny, 2004).

The issue of the relationship of the agrarian market with other markets is also related to the issue of agricultural market objects. Thus, in the scientific literature and in the Ukrainian legislation, along with the term "agrarian market", the terms "agricultural market", "agri-food market" and some others are used. In particular, these terms are used in regulations on the implementation of the state agricultural policy. This presupposes the concretization of the meaning of these terms, their comparison with the aim to establish similarities or state the differences between them. It is believed that the baseline for determining the relationship between these terms and the markets they represent, you should also put the objects of circulation in the market.

Using the object criterion, it should be agreed that the terms "agrarian market" and "market of agricultural products" can be considered as synonymous (Pavlenchyk, 2014: 88).

Considering the balance between the agricultural and agri-food market one should turn to the analysis of the Ukrainian legislation. Thus, the agri-food market is defined as an economic entity that creates the appropriate conditions for the sale (wholesale) of agricultural products, including food, in specially equipped and designated places in accordance with the law (Pro osnovni pryntsypy ta vymohy do bezpechnosti ta yakosti kharchovykh produktiv, 1997). Thus, exclusively as only the legal concepts have legal definitions, the agrarian market and the agri-food market are different concepts, because the agrarian market is a set of legal relations, while the agri-food market is a business entity.

Instead, if we take into consideration the scientific views on the agri-food market, we can get a different conclusion about the relationship between these concepts. It is considered that the agri-food market includes three subsystems, in particular, the market of livestock and industrial products, the market of crop and industrial products and the market of agricultural by-products and products of their processing (Samoilyk, 2016: 167). In this approach, the concept of agri-food market is broader than the concept of the agrarian market, because the object of circulation in the agri-food market may be the part of the plant and animal agricultural products, which may simultaneously belong to food products. However, the object of circulation in the agrarian market may also be agricultural products intended for use in the pharmaceutical industry, light industry, biofuel production, etc. Therefore, the terms "agrarian market" and "agri-food market" can be considered as partially intersecting.

Defining the agrarian market and establishing its relationship with the similar concepts for the practical sphere may seem quite conventional, as each of these markets has no significant barriers, affects the functioning of other markets, the agricultural producers and others can be almost simultaneously participants in the agrarian, and agrifood market and other markets. However, such a distinction is important for a clear understanding of the limits of the spread of certain rules, regulations and prohibitions and the direction of the state regulation. In addition, in order to achieve a greater efficiency of the state agricultural policy, the concepts of the agrarian market and the related concepts require clear legislative definitions or revision of regulations in order to unify terminology.

Evaluating all the above mentioned, we can emphasize once again that the market and the agrarian market are complex and multifaceted concepts that are actively used in law and in practice, are studied by scientists.

Regardless of the concept within which the concept of the market is considered, the main characteristics of the market are preserved and taken into account, in particular, the relationship with the sphere of production, the coordination of supply and demand, the formation of prices for objects of circulation.

The analyzed approaches to the understanding of the agrarian market as a system of relations, the sphere of circulation and the mechanism of regulation should not be considered contradictory, but, on the contrary, such as to focus on a certain aspect of this complex economic and legal phenomenon.

The approach to defining the concept of the agrarian market as a system of social relations, which are regulated by law, will identify the parties and the object of such social relations, the reasons for their emergence and to suggest the legal forms of intercession of agricultural products.

Understanding the agrarian market as a sector of commodity circulation allows a broader look at the objects and, accordingly, at the types of the agrarian market, its participants and market infrastructure, the set of relations that may arise between these participants and accompany the exchange of agricultural products, to take into account certain features of the agrarian market, which are outside the structure of the market as a legal relationship.

The approach to understanding the agrarian market as a mechanism for regulating the interaction of the trade participants allows to take into account the factors and features inherent in the agrarian market (e.g., seasonality and cyclical supply of certain agricultural products, the reduced shelf life of certain products, a high costs of transportation, storage, a pre-sale preparation, etc.). Therefore, this approach is important for developing the optimal relationship between the government regulation and self-regulatory market function, which is crucial for the agrarian market.

Conclusion. Based on the research done, it can be generalized that the concept of the market is interpreted as a set (system) of relations governed by law, as a sphere of circulation of goods and, less often, as a regulatory mechanism in the law field.

Based on a common understanding of the market, the concepts are developed for the different types of markets, including the agrarian market. Disclosure and consideration of the peculiarities of the agrarian market in the context 
of these conceptual approaches allows a better understanding of the essence of the agrarian market as an object of research and legal regulation.

For the general legislative definition of the agrarian market, it is possible to take as a basis the understanding of this concept as a system of social relations governed by the rules of law that arise in relation to the sale of agricultural products. This will allow us to evaluate the legislation aimed to regulate the agrarian market through the structure of legal relations and the grounds for their occurrence (changes and termination).

In the context of improving the legal regulation of the agrarian market and for the purposes of forming the state agricultural policy, specifying the means of the state regulation it is obvious to take into account the definition of the market as a sphere of trade and as a regulatory mechanism. This will give the opportunity to identify those aspects of the agrarian market that require the government regulation, in view of the necessity to ensure the effective functioning of this market.

Also, the effectiveness of legal support for the functioning of the agrarian market depends on a clear legislative definition and the definition of all related concepts, which requires the amendments to the regulations or revision of their provisions in order to unify the terminology.

1. Baker, J. Market definition: an analytical overview. Antitrust Law Journal. 2007. 74 (1). P. 129-173. URL: www.jstor.org/stable/27897544.

2. Kaplow L. Market Definition: Impossible and Counterproductive. Antitrust: Antitrust Law \& Policy eJournal. 2013. Vol. 79. № 1. P. 361-379. URL: https://leconcurrentialiste.files.wordpress.com/2015/01/market-definitionimpossible-and-counterproductive.pdf.

3. Бачуріна І.В. Сутність поняття «аграрний ринок». Економіка АПК. 2009. № 10. С. 108-111.

4. Григор'єв С.О., Кваша С.М. Сутність та особливості аграрного ринку Вісник Одеського національного університету. Серія «Економіка». 2016. Т. 21. Вип. 8. С. 56-59. URL: http://nbuv.gov.ua/UJRN/Vonu_econ_2016_21_8_13.

5. Carlton, Dennis W. Market Definition: Use and Abuse. Competition Policy International. 2007. Vol. 3. № 1. URL: https://ssrn.com/abstract=987061.

6. Crane D. Market Power Without Market Definition. Notre Dame Law Review. 2014. № 90. P. 31-80. URL: http://ndlawreview.org/wp-content/uploads/2013/05/NDL102_crop.pdf

7. Словник української мови : в 11 т. Київ, 1977. Термін «Ринок». Том 8. С. 536. URL: http://sum.in.ua/s/rynok.

8. Павленчик Н.Ф. Теоретичні основи обгрунтування дефініції «ринок сільськогосподарської продукції». Економіка АПК. 2014. № 1. С. 85-92. URL: http://eapk.org.ua/sites/default/files/eapk/14_01_85-92.pdf.

9. Каламан О.Б. Теоретичні складові, особливості управління, розвиток поняття ринку продукції виноградарства. Економічний аналіз : зб. наук. праць / ТНЕУ ; редкол.: В.А. Дерій (голов. ред.) та ін. Тернопіль : Видавничо-поліграфічний центр Тернопільського національного економічного університету «Економічна думка», 2015. Том 21. № 1. С. 50-55.

10. Економічна енциклопедія : у 3 т. / Б. Гаврилишин (гол. ред.) Київ : Вид. центр «Академія». 2000-2002. Т. 3. 952 с.

11. Прилуцький Р.Б. Правові механізми у сфері господарювання. Юридична наука. 2013. № 5. С. $26-39$. URL: http://nbuv.gov.ua/UJRN/jnn_2013_5_5.

12. Смагін В.Л. Формування та розвиток фінансового ринку в умовах трансформаційної економіки : монографія. Київ : KHEУ, 2008. $232 \mathrm{c}$.

13. Основи економічної теорії: підручник / В.Г. Федоренко, Ю.В. Ніколенко, О.М. Діденко, М.М. Руженський ; за наук. ред. проф. В.Г. Федоренка. Київ : Алерта, 2007. 519 с.

14. Кирилюк Є.М. Аграрниий ринок як економічна категорія: сутнісні ознаки й особливості. Агросвіт. 2011. № 12. URL: http://www.agrosvit.info/pdf/12_2011/2.pdf.

15. Мамчур В.А. Аграрний ринок як інститут розвитку аграрного бізнесу. Ефективна економіка. 2013. № 9. URL: http://www.economy.nayka.com.ua/?op=1\&z=2342.

16. Ворон Р.О. Господарсько-правове забезпечення розвитку фармацевтичного ринку в Україні : автореф. дис. ... канд. юрид. наук : 12.00.04. Харків, 2015. 23 с.

17. Полюхович В.І. Господарсько-правовий механізм державного регулювання фондового ринку України : автореф. дис. ... докт. юрид. наук : 12.00 .04 . Харків, 2012. 40 с.

18. Куценко А.О. Господарсько-правове забезпечення діяльності суб'єктів господарювання на ринку м'ясо-молочної продукції : автореф. дис. ... канд. юрид. наук : 12.00.04. Харків, 2012. 23 с.

19. Семчик В.I. Навчаючись, навчаю... Вибрані праці. Київ : Спринт-Сервіс, 2012, 596 с.

20. Термінологія законодавства. Термін «Ринок». Сайт Верховної Ради України. URL: https://zakon.rada.gov.ua/laws/ term/25898/sp:max 100 .

21. Про державну підтримку сільського господарства України : Закон України від 24 червня 2004 р. № 1877-IV. Відомості Верховної Ради України. 2004. № 49. Ст. 527.

22. О развитии сельского хозяйства : Закон Российской Федерации от 29 декабря 2006 г. № 264-ФЗ. URL: http://base.garant.ru/12151309/1b93c134b90c6071b4dc3f495464b753/.

23. Угода про спільний аграрний ринок держав-учасниць Співдружності Незалежних Держав від 6 березня 1998 р. URL: https://zakon.rada.gov.ua/laws/card/en/997_153?lang=uk.

24. Договір про заснування Свропейської Спільноти : Міжнародний документ від 25 березня 1957 p. (редакція від 1 січня 2005 p). URL: https://zakon.rada.gov.ua/laws/show/994_017\#Text.

25. Про основні принципи та вимоги до безпечності та якості харчових продуктів : Закон України від 23 грудня $1997 \mathrm{p}$. № 771/97-ВР. Відомості Верховної Ради України. 1998. № 19. Ст. 98.

26. Самойлик Ю. Концептуальна сутність і структура агропродовольчого ринку. Agricultural and Resource Economics: International Scientific E-Journal. 2016. Vol. 2. № 4. P. 161-173. URL: www.are-journal.com. 


\section{References:}

1. Baker, J. (2007). Market definition: an analytical overview. Antitrust Law Journal. Vol. 74 (1). P. 129-173. Available at: http://www.jstor.org/stable/27897544 [in English].

2. Kaplow, L. (2013). Market Definition: Impossible and Counterproductive. Antitrust: Antitrust Law \& Policy eJournal. Vol. 79 , No. 1. P. 361-379. Available at: https://leconcurrentialiste.files.wordpress.com/2015/01/market-definition-impossible-andcounterproductive.pdf [in English].

3. Bachurina, I.V. (2009). Sutnist poniattia «ahrarnyi rynok». [The essence of the concept of «agricultural market»]. Ekonomika $A P K$. № 10. P. 108-111 [in Ukrainian].

4. Hrigoryev, S.Î., Kvasha, S.M. (2016). Sutnist ta osoblyvosti ahrarnoho rynku [Essence and Features of Agricultural Market]. Visnyk Odeskoho natsionalnoho universytetu. Seriia: Ekonomika. T. 21. Vyp. 8. P. 56-59. Available at: http://nbuv.gov.ua/ UJRN/Vonu econ 2016218 [3 [in Ukrainian].

5. Carlton, Dennis W. (2007). Market Definition: Use and Abuse. Competition Policy International. Vol. 3, No. 1. Available at SSRN: https://ssrn.com/abstract=987061 [in English].

6. Crane, D. (2014). Market Power Without Market Definition. Notre Dame Law Review, No. 90. P. 31-80. Available at: http://ndlawreview.org/wp-content/uploads/2013/05/NDL102_crop.pdf [in English].

7. Slovnyk ukrainskoi movy: v 11 tomakh. (1977). [Dictionary of the Ukrainian language: in 11 volumes]. Termin rynok. Vol. 8. P. 536. Available at: http://sum.in.ua/s/rynok [in Ukrainian].

8. Pavlenchyk, N.F. (2014). Teoretychni osnovy obgruntuvannia definitsiï «rynok silskohospodarskoï produktsiï» [Theoretical bases of substantiation of the definition «market of agricultural products»]. Ekonomika APK. No. 1. P. 85-92. Available at: http://eapk.org.ua/sites/default/files/eapk/14_01_85-92.pdf [in Ukrainian].

9. Kalaman, O.B. (2015). Teoretychni skladovi, osoblyvosti upravlinnya, rozvytok ponyattya rynku produktsiï vynohradarstva [Theoretical components, features of management, development of concept of the market of production of viticulture] . V.A. Deriy (ed.) and et. Ekonomichnyy̆ analiz: zb. nauk. prats. Vol. 21. No. 1. P. 50-55 [in Ukrainian].

10. Ekonomichna entsyklopediia v 3 tomakh. (2002). [Economic Encyclopedia: in 3 volumes] / B. Havrylyshyn (ed.). Vol. 3. K.: Vyd. tsentr «Akademiia». P. 235 [in Ukrainian].

11. Prylutskiy, R.B. (2013). Pravovi mekhanizmy u sferi hospodariuvannia [Legal mechanisms in the sphere of management]. Yurydychna nauka. No. 5. P. 26-39. Available at: http://nbuv.gov.ua/UJRN/jnn_2013_5_5 [in Ukrainian].

12. Smahin, V.L. (2008). Formuvannya ta rozvytok finansovoho rynku v umovakh transformatsiynoyi ekonomiky: Monohrafiya. [Formation and development of the financial market in a transformational economy: Monograph.] K.: KNEU, 2008. 232 p. [in Ukrainian].

13. Nikolenko, Yu.V., Didenko, O.M., Ruzhens'kyy, M.M. Fedorenko, V.H. (Ed). (2007). Osnovy ekonomichnoyi teoriyi: pidruchnyk [Fundamentals of economic theory: a textbook]. K.: Alerta. 519 p. [in Ukrainian].

14. Kyrylyuk, Ye.M. (2011). Ahrarnyy rynok yak ekonomichna katehoriya: sutnisni oznaky y osoblyvosti [The agricultural market as an economic category: essential features and features]. Ahrosvit. No. 12. Available at: http://www.agrosvit.info/ pdf/12_2011/2.pdf [in Ukrainian].

15. Mamchur, V.A. (2013). Ahrarnyy rynok yak instytut rozvytku ahrarnoho biznesu [Agrarian market as an institution of agrarian business development]. Efektyvna ekonomika. No. 9. Available at: http://www.economy.nayka.com.ua/?op=1\&z=2342 [in Ukrainian].

16. Voron, R.O. (2015). Hospodars'ko-pravove zabezpechennya rozvytku farmatsevtychnoho rynku v Ukrayini: avtoref. dys. kand. yurid. nauk [Business legal maintainence of the pharmaceutical market in Ukraine. Retaining manuscript rights]. Kharkiv. 23 p. [in Ukrainian].

17. Polyukhovych, V.I. (2012). Hospodars'ko-pravovyy mekhanizm derzhavnoho rehulyuvannya fondovoho rynku Ukrayiny: avtoreferat dys. ... d-ra yuryd. nauk [Economic and legal mechanism of state regulation of the stock market of Ukraine Retaining manuscript rights]. Kharkiv. 40 p. [in Ukrainian].

18. Kutsenko, A.O. (2012). Hospodars'ko-pravove zabezpechennya diyal'nosti sub"yektiv hospodaryuvannya na rynku m"yasomolochnoyi produktsiyi: avtoref. dys. kand. yurid. nauk [Economic and legal support of economic entities on the market of meat and dairy products. - Manuscript]. Kharkiv. 23 p. [in Ukrainian].

19. Semchyk, V.I. (2012). Navchayuchys', navchayu... Vybrani pratsi [While studying, I teach... Selected works]. K.: SpryntServis. 596 p. [in Ukrainian].

20. Terminolohiya zakonodavstva (2020). Termin «Rynok» [Terminology of legislation. The term «Market»]. Sayt Verkhovnoyi Rady Ukrayiny. Available at: https://zakon.rada.gov.ua/laws/term/25898/sp:max100 [in Ukrainian].

21. Pro derzhavnu pidtrymku sil's'koho hospodarstva Ukrayiny (2004) [On State Support for Agriculture in Ukraine]: Zakon Ukrayiny vid 24.06.2004 r. № 1877-IV. Vidomosti Verkhovnoyi Rady Ukrayiny. No. 49. St. 527 [in Ukrainian].

22. O razvitii sel'skogo khozyaystva (2006) [On the development of agriculture]: Zakon Rossiyskoy Federatsii ot 29.12.2006. No. 264-FZ. Available at: http://base.garant.ru/12151309/1b93c134b90c6071b4dc3f495464b753/ [in Russian].

23. Uhoda pro spil'nyy ahrarnyy rynok derzhav-uchasnyts' Spivdruzhnosti Nezalezhnykh Derzhav (1998) [Agreement on the Common Agricultural Market of the Member States of the Commonwealth of Independent States] vid 06.03.1998. Available at: https://zakon.rada.gov.ua/laws/card/en/997 153?lang=uk [in Ukrainian].

24. Dohovir pro zasnuvannya Yevropeys'koyi Spil'noty. (2005). [Reaty on the Functioning of the European Union]: Mizhnarodnyy dokument vid 25.03.1957. (redaktsiya vid 01.01.2005). Available at: https://zakon.rada.gov.ua/laws/show/994_017\#Text [in Ukrainian].

25. Pro osnovni pryntsypy ta vymohy do bezpechnosti ta yakosti kharchovykh produktiv (1997) [On Quality and Safety of Food Products and Food Raw Materials]. Zakon Ukrayiny vid 23.12.1997. No. 771/97-VR. Vidomosti Verkhovnoyi Rady Ukrayiny. No. 19. St. 98 [in Ukrainian].

26. Samoilyk, Iu. (2016). Kontseptual'na sutnist' i struktura ahroprodovol'choho rynku [Concept essence and structure of agrifood market]. Agricultural and Resource Economics: International Scientific E-Journal. Vol. 2. No. 4. P. 161-173. Available at: www.are-journal.com [in Ukrainian]. 